\title{
PENGARUH DUKUNGAN SPIRITUAL TERHADAP PENURUNAN TINGKAT KECEMASAN PADA PASIEN PRE OPERASI DI RUANG BEDAH RSUD DEPATI BAHRIN KABUPATEN BANGKA
}

\author{
Kgs. M. Faizal ${ }^{1}$, Kartini Eka Putri ${ }^{2}$ \\ ${ }^{1}$ Dosen STIKES Citra Delima Bangka Belitung \\ Email: faizalcd14@gmail.com \\ ${ }^{2}$ Mahasiswa STIKES Citra Delima Bangka Belitung \\ Email: kartiniekaputri@gmail.com
}

\section{ABSTRACK: THE EFFECT OF SPIRITUAL SUPPORT ON DECREASING LEVELS OF ANXIETY OF PRE OPERATING PATIENTS IN SURGERY ROOM RSUD DEPATI BAHRIN OF BANGKKA REGENCY HOSPITAL IN 2019}

Background : Operation is a potential and actual threat to the integrity of a person who can evoke physiological and psychological stress reactions, and is a difficult experience for almost all patients. Various bad possibilities can occur that will endanger the patient. So do not be surprised if often patients and families show excessive attitude with anxiety experienced. One of the nursing interventions that can be done is spiritually. Based on data from operating patients from the Depati Bahrin Regional Hospital in Bangka Regency, data was obtained in 2016 there were 1.317 patients, in 2017 there were 1.290 patients, data in 2018 there were 1.028 patients operating.

Purpose : The purpose of this study was to determine the effect of spiritual support on reducing anxiety levels in preoperative patients in the Depati Bahrin of Bangka Regency Hospital Surgery Room in 2019.

Method : The study was conducted using a simple quasi experimental research design with pre-poest intervention. Samples were taken by non probability sampling method, namely 36 respondents divided into two groups, 18 respondents in the intervention group and 18 respondents in the control group. The statistical test analysis used in this study was the independent $t$-test and dependent t-test or paired t-test.

Result : The results showed that there were differences in the level of anxiety obtained $p$ value $=0,000$ in the intervention group, while the control group obtained a value of $p=0.210$, it can be concluded that there is a significant difference between the level of anxiety before and after the intervention and control groups.

Conclusion : Suggestions researchers should hospitals take a policy about the implementation of meeting the spiritual needs of patients preoperatively by involving spiritual teachers.

Keywords: Support, Spiritual, Anxiety, Patient, Preoperative 
INTISARI: PENGARUH DUKUNGAN SPIRITUAL TERHADAP PENURUNAN TINGKAT KECEMASAN PASIEN PRE OPERASI DI RUANG BEDAH RSUD DEPATI BAHRIN KABUPATEN BANGKA

Pendahuluan : Tindakan pembedahan merupakan ancaman potensial maupun aktual pada integritas seseorang yang dapat membangkitkan reaksi stress fisiologis maupun psikologis, dan merupakan pengalaman yang sulit bagi hampir semua pasien. Berbagai kemungkinan buruk bisa terjadi yang akan membahayakan bagi pasien. Maka tidak heran jika sering kali pasien dan keluarga menunjukkan sikap yang berlebihan dengan kecemasan yang dialami. Salah satu intervensi keperawatan yang bisa dilakukan adalah dengan spiritual. Berdasarkan data pasien operasi dari RSUD Depati Bahrin Kabupaten Bangka diperoleh data pada tahun 2016 terdapat 1.317 orang pasien, data tahun 2017 tedapat 1.290 orang pasien, data pada tahun 2018 terdapat 1.028 pasien operasi.

Tujuan : Untuk mengetahui pengaruh dukungan spiritual terhadap penurunan tingkat kecemasan pada pasien pre operasi di Ruang Bedah RSUD Depati Bahrin Sungailiat Tahun 2019.

Metode : Penelitian dilakukan dengan menggunakan desain penelitian quasi eksperiment sederhana dengan pre-poest intervensi. Sampel diambil dengan metode non probability sampling yaitu 36 responden yang terbagi dua kelompok, 18 responden kelompok intervensi dan 18 responden kelompok kontrol. Analisis uji statistik yang digunakan dalam penelitian ini adalah uji Independen t-test dan dependen t-test atau paired t-test.

Hasil Penelitian : Hasil penelitian diketahui ada perbedaan tingkat kecemasan didapatkan nilai $p=0,000$ pada kelompok intervensi, Sedangkan kelompok kontrol didapatkan nilai $p=0,210$ maka dapat disimpulkan bahwa ada perbedaan yang signifikan antara tingkat kecemasan sebelum dan sesudah pada kelompok intervensi dan kontrol.

Kesimpulan : Saran peneliti sebaiknya rumah sakit mengambil kebijakan tentang penerapan pemenuhan kebutuhan spirituak pasien pre operasi dengan cara melibatkan guru spiritual.

Kata Kunci : Dukungan, Spiritual, Kecemasan, Pasien, Pre Operasi

\section{PENDAHULUAN}

Operasi merupakan semua tindakan pengobatan yang menggunakan cara invasif dengan membuka atau menampilkan bagian tubuh yang akan ditangani. Pembukaan tubuh ini umumnya dilakukan dengan membuat sayatan. Setelah melihat bagian yang akan ditangani dan dilakukan tindakan perbaikan yang akan diakhiri dengan penutupan dan penjahitan luka (Sjamsuhidajat, 2010). Pembedahan terdiri dari tiga fase: pre-operatif, intra-operatif, dan pasca-operatif. Fase pre-operatif dimulai saat keputusan untuk melakukan pembedahan dibuat dan berakhir ketika klien dipindahkan ke meja operasi (Kozier, 2009)

Berdasarkan data yang diperoleh dari World Health Organization (WHO) dalam Sartika (2013), jumlah pasien dengan tindakan operasi mencapai angka peningkatan yang sangat signifikan dari tahun ke tahun. Tercatat di tahun 2011 terdapat 140 juta pasien di seluruh rumah sakit di dunia, dan pada tahun 2012 data mengalami peningkatan sebesar 148 juta jiwa, sedangkan untuk di Indonesia pada tahun 2012 mencapai 1,2 juta jiwa (Sartika,2013). 
Pasien yang akan dilakukan operasi tentunya akan mengalami kecemasan, Cemas merupakan respon individu terhadap suatu keadaan yang tidak menyenangkan, pengalaman subjektif dari individu dan tidak dapat diobservasi secara langsung serta merupakan suatu keadaan emosi tanpa objek yang spesifik (Suherlan, 2012). Kecemasan adalah satu kondisi kegelisahan mental, keprihatinan, ketakutan, firasat atau perasaan putus asa karena ancaman yang akan terjadi atau ancaman antisipasi yang tidak dapat diidentifikasi terhadap diri sendiri atau terhadap hubungan yang bermakna. Pengertian lain cemas adalah suatu keadaan yang membuat seseorang yang tidak nyaman dan terbagi dalam tingkatan. Jadi, cemas berkaitan dengan perasaan yang tidak pasti dan tidak berdaya (Kusumawati dan Hartono, 2010).

Dari hasil penelitian yang dilakukan Apriansyah, dkk (2014), dengan judul hubungan antara tingkat kecemasan pre operasi dengan derajat nyeri pada pasien post sectio caesarea di rumah sakit muhammadiyah palembang tahun 2014 menyatakan ada hubungan yang signifikan antara tingkat kecemasan pre operasi dengan derajat nyeri post sectio caesarea. Dari hasil uji statistik menunjukan ada hubungan yang signifikan antara tingkat kecemasan pre operasi dengan derajat nyeri post sectio caesarea dengan $p$ value 0,010.

Dalam penelitian Darma, dkk (2017), dalam beberapa penelitian kini telah banyak dikembangkan terapi keperawatan untuk mengatasi kecemasan, seperti relaksasi nafas dalam, imajinasi terbimbing, penafasan diafragma, relaksasi otot pogresif, masase, yoga dan lainnya. Salah satu cara mengatasi kecemasan yaitu dengan cara pemenuhan kebutuahan spiritual pasien.

Menurut Rozalino (2009) dikutip dari Agusnawati (2013), salah satu upayanya dalam intervesi keperawatan untuk mencegah ansietas adalah dengan terapi spiritual. Terapi spiritual merupakan suatu pengobatan alternatif dengan cara pendekatan keagamaan melalui doa dan dzikir yang merupakan unsur penyembuhan penyakit atau sebagai psikoterapeutik yang mendalam, bertujuan untuk membangkitkan rasa percaya diri dan optimisme yang paling penting selain obat dan tindakan medik.

Dalam penelitian Rahmayati, dkk (2018), menurut Alexis Carrel dalam bukunya berjudul Pray (Doa) tentang pengalamannya dalam mengobati pasien. Banyak diantara pasiennya memperoleh kesembuhan dengan jalan berdoa. Doa adalah suatu gejala keagamaan yang paling agung bagi manusia karena pada saat itu jiwa manusia terbang menuju Tuhannya. Kalaupun apa yang dimohonkan tidak sepenuhnya terpenuhi, namun dengan doa tersebut seseorang telah hidup dalam suasana optimisme, harapan dan ketenangan batin.

Dari hasil penelitian yang dilakukan Rahmayati, dkk (2017), dengan judul pengaruh dukungan spiritual terhadap tingkat kecemasan pada pasien pre-operasi menyatakan hasil uji statistik didapat nilai $p$ value 0,001 maka dapat disimpulkan bahwa ada pengaruh terapi dukungan spiritual terhadap tingkat kecemasan pada pasien pre-operasi di RS Imanuel Provinsi Lampung Tahun 2017. dari hasil penelitian tersebut disarankan terapi dukungan spiritual sebagai asuhan keperawatan pada pasien yang mengalami kecemasan.

Berdasarkan data yang peneliti dapat, data pasien operasi di RSUD Depati Hamzah Pangkalpinang di 
peroleh data pada tahun 2016 terdapat 620 orang pasien, data pada tahun 2017 terdapat 534 orang pasien, data pada tahun 2018 terdapat 445 orang pasien. Ditempat yang berbeda data yang peneliti dapat dari petugas diruang rekam medis, pasien yang menjalani pembedahan umum di RSUD Depati Bahrin Kabupaten Bangka diperoleh data tahun 2016 terdapat 1.317 orang pasien, data pada tahun 2017 terdapat 1.290 orang pasien, data pasien 2018 terdapat 1.028 orang pasien.

Hasil survei awal yang peneliti lakukan pada tanggal 9 dan 10 maret 2019 tentang tingkat kecemasan pre operasi di Ruang Bedah RSUD Depati Bahrin Kabupaten Bangka, bahwa dari 10 orang responden yang akan menjalankan operasi dalam tingkat kecemasan sedang 4 orang, 3 orang tingkat kecemasan ringan, dan 3 orang tidak mengalami kecemaasan. Dari hasil wawancara peneliti dengan 3 pasien yang akan menjalankan operasi, pasien mengatakan merasa cemas karena akan dioperasi dan ini pengalaman pertama menjalankan operasi. Hasil observasi yang peneliti lakukan diruang bedah, untuk pelaksaan pemenuhan kebuthan spiritual yang dilakukan perawat saat ini kurang, perawat hanya menjelaskan bagaimana prosedur yang akan di jalani saat akan operasi. Hasil wawancara yang peneliti lakukan dengan perawat di Ruang Bedah RSUD Depati Bahrin Kabupaten Bangka didapatkan data bahwa dalam menangani kecemasan pasien pre operasi perawat memberikan pendidikan kesehatan mengenai informasi tentang prosedur pembedahan yang akan dilakukan dan mengajarkan teknik relaksasi nafas dalam.

Bahwa di RSUD Depati Bahrin Kabupaten Bangka belum adanya intervensi terkait pemenuhan dukungan spritual pada pasien pre operasi sehingga pentingnya mengetahui pengaruh dukungan spiritual terhadap tingkat kecemasan pada pasien pre operasi, maka dari itu peneliti tertarik untuk meneliti lebih lanjut tentang pengaruh dukungan spiritual terhadap tingkat kecemasan pasien pre operasi.

\section{METODE}

Penelitian ini merupakan jenis penelitian yang bersifat kuantitatif dengan desain penelitian yaitu Quasi eksperiment sederhana dengan prepost intervensi.

Desain rancangan yang digunakan yaitu pendekatan pre dan post test contol group design. Pengaruh pemberian dukungan spiritual dilakukan pengukuran skala perununan tingkat kecemasan untuk melihat pengaruh dukungan spiritual terhadap penurunan tingkat kecemasan pada pasien pre operasi di ruang bedah RSUD Depati Bahrin Sungailiat tahun 2019. Penelitian ini dilakukan pada pagi dan sore hari. Instrument yang digunakan untuk mengukur tingka kecemasan adalah Hamilton Rating Scale For Anxiety (HARS) dengan mengisi skor 0-4.

Berdasarkan data RSUD Depati Bahrin Sungailiat populasi pasien operasi tahun 2018 sebanyak 445 orang. penelitian ini menggunakan 36 responden dibagi menjadi 2 kelompok. Kelompok intervensi berjumlah 18 orang dan kelompok kontrol berjumlah 18 orang.

Penelitian ini telah lolos uji etik yang diselenggarakan oleh tim UPPM STIKES Citra Delima Bangka Belitung 


\section{HASIL PENELITIAN}

Hasil analisa statistik univariat pada penelitian ini menggambarkan karakteristik responden yang meliputi, jenis kelamin dan usia. Karakteristik tingkat kecemasan responden. Data lain yang disajikan pada analisa univariate ini adalah gambaran tingkat kecemasan sebelum dan sesudah dilakukan dukungan spiritual. Hasil dari variabel-variabel tersebut dapat dilihat pada tabletabel berikut :

Tabel 1

Distribusi Responden Berdasarkan Jenis Kelamin Pasien Pre Operasi di Ruang Bedah RSUD Depati Bahrin Kabupaten Bangka

\begin{tabular}{|c|c|c|c|c|}
\hline \multirow[t]{2}{*}{$\begin{array}{l}\text { Karakterist } \\
\text { ik } \\
\text { Responden }\end{array}$} & \multicolumn{2}{|c|}{$\begin{array}{c}\text { Kelompo } \\
\mathbf{k} \\
\text { Interven } \\
\text { si }\end{array}$} & \multicolumn{2}{|c|}{$\begin{array}{c}\text { Kelompo } \\
\mathbf{k} \\
\text { Kontrol }\end{array}$} \\
\hline & $\mathbf{N}$ & $\%$ & $n$ & $\%$ \\
\hline Jenis & & & & \\
\hline Kelamin & 7 & 38,9 & 8 & 44,4 \\
\hline $\begin{array}{l}\text { Laki-laki } \\
\text { Perempuan }\end{array}$ & 11 & 61,1 & 10 & 55,6 \\
\hline Total & 18 & 100 & 18 & 100 \\
\hline
\end{tabular}

Berdasarkan Tabel 1 dapat diketahui bahwa pada kelompok intervensi dari 18 responden yang berjenis kelamin laki-laki ada 7 dan 11 perempuan, pada kelompok intervensi jenis kelamin perempuan lebih banyak dari pada laki-laki. Sedangkan pada kelompok kontrol dari 18 responden yang berjenis kelamin laki-laki berjumlah 8 orang dan perempuan berjumlah 10 orang, pada kelompok kontrol jenis kelamin perempuan juga lebih banyak dibandingkan dengan laki-laki.
Tabel 2

Distribusi Responden Berdasarkan Umur Pre Operasi di Ruang bedah RSUD Depati Bahrin Kabupaten Bangka

\begin{tabular}{cccccc}
\hline Variabel & $\mathrm{N}$ & Mean & SD & $\begin{array}{c}\text { Min- } \\
\text { Mak }\end{array}$ & $\begin{array}{c}95 \% \\
\mathrm{Cl}\end{array}$ \\
\hline $\begin{array}{c}\text { Intervensi } \\
\text { Umur }\end{array}$ & 18 & 48,06 & 8,530 & $\begin{array}{r}34- \\
60\end{array}$ & $\begin{array}{c}43,81- \\
52,30\end{array}$ \\
\hline $\begin{array}{c}\text { Kontrol } \\
\text { Umur }\end{array}$ & 18 & 43,28 & 9,285 & $\begin{array}{c}20- \\
55\end{array}$ & $\begin{array}{c}38,66- \\
47,90\end{array}$ \\
\hline
\end{tabular}

Berdasarkan tabel 2 dapat diketahui bahwa usia responden pada kelompok intervensi paling rendah usianya 34 tahun dan usia responden paling tinggi 60 tahun, sedangkan pada kelompok kontrol usia paling rendah adalah 20 tahun dan usia paling tinggi adalah 55 tahun.

Tabel 3

Distribusi Responden Berdasarkan Tingkat Kecemasan Sebelum dilakukan Dukungan Spiritual Pada Pasien Pre Operasi di Ruang Bedah RSUD Depati Bahrin Kabupaten Bangka

\begin{tabular}{|c|c|c|}
\hline & Intervensi & Kontrol \\
\hline Kategori & $\mathrm{n}$ & $\mathbf{N}$ \\
\hline
\end{tabular}

$\begin{array}{lllll}\text { Tidak Ada } & 1 & 5,6 & 3 & 16,7\end{array}$

$\begin{array}{lllll}\text { Cemas Ringan } & 14 & 77,8 & 11 & 61,1\end{array}$

$\begin{array}{lllll}\text { Cemas Sedang } & 3 & 16,7 & 4 & 22,2\end{array}$

$\begin{array}{lllll}\text { Total } & 18 & 100 & 18 & 100\end{array}$
Berdasarkan Tabel 3 dapat diketahui bahwa pada kelompok intervensi sebelum dilakukan dukungan spiritual sebagian besar berada pada tingkat kecemasan ringan yaitu 14 orang, sedangkan pada kelompok kontrol sebagian besar juga berada pada tingkat kecemasan ringan sebanyak 11 orang. 
Tabel 4

Distribusi Responden Berdasarkan Tingkat Kecemasan Sesudah dilakukan Dukungan Spiritual Pada Pasien Pre Operasi di Ruang Bedah RSUD Depati Bahrin Kabupaten Bangka

\begin{tabular}{ccccc}
\hline \multirow{2}{*}{ Kategori } & \multicolumn{2}{c}{ Intervensi } & \multicolumn{2}{c}{ Kontrol } \\
\cline { 2 - 5 } & $\mathbf{n}$ & $\%$ & $\mathbf{N}$ & $\%$ \\
\hline Tidak Ada & 10 & 55,6 & 3 & 16,7 \\
Cemas Ringan & 8 & 44,4 & 12 & 66,7 \\
\hline Cemas Sedang & 0 & 0 & 3 & 16,7 \\
\hline Total & 18 & 100 & 18 & 100 \\
\hline
\end{tabular}

perbedaan yang signifikan antara tingkat kecemasan sebelum dan sesudah dilakukan dukungan spiritual pada kelompok intervensi. Pengukuran dilakukan dengan uji statistik dependen $t$-test

Tabel 6

Analisa Rata-Rata Skor Tingkat Kecemasan pada Kelompok Kontrol Sebelum dan Sesudah dilakukan Dukungan Spiritual

Sebelum dan Sesudah Perlakuan di RSUD Depati Bahrin Kabupaten Bangka Tahun 2019

Berdasarkan Tabel 4 dapat diketahui bahwa pada kelompok intervensi sesudah dilakukan dukungan spiritual sebagian besar berada pada tingkat tidak ada kecemasan yaitu 10 orang, sedangkan pada kelompok kontrol sebagian besar berada pada tingkat kecemasan ringan sebanyak 12 orang.

\begin{tabular}{ccccc}
\hline Variabel & $\mathbf{N}$ & Mean & SD & $\begin{array}{c}\boldsymbol{p} \\
\text { value }\end{array}$ \\
\hline $\begin{array}{c}\text { Kontrol } \\
\text { Sebelum }\end{array}$ & 18 & 16,28 & 3,707 & 0,210 \\
$\begin{array}{c}\text { Sesudah } \\
18\end{array}$ & 16,61 & 3,696 & \\
\hline
\end{tabular}

Pada table 6 menunjukkan rata-rata tingkat kecemasan sebelum dilakukan perlakuan pada kelompok kontrol adalah 16,28 (SD=3,707). Sedangkan rata-rata skor tingkat kecemasan sesudah dilakukan perlakuan adalah 16,61 (SD=3,696). Hasil uji statistik didapatkan nilai $p$ $=0,210$ maka dapat disimpulkan bahwa tidak ada perbedaan yang signifikan antara tingkat kecemasan sebelum dan sesudah pada kelompok kontrol. Pengukuran dilakukan dengan menggunakan uji statistik dependen $t$-test.

Analisis Rata-rata Skor Tingkat Kecemasan Pada Kelompok Intervensi Sebelum dan Sesudah Perlakuan di RSUD Depati Bahrin Kabupaten Bangka Tahun 2019

\begin{tabular}{|c|c|c|c|c|}
\hline Variabel & $\mathbf{N}$ & Mean & SD & $\begin{array}{c}p \\
\text { value }\end{array}$ \\
\hline Intervens & & & & \\
\hline $\begin{array}{l}\text { i } \\
\text { Sebelum } \\
\text { Sesudah }\end{array}$ & $\begin{array}{l}18 \\
18\end{array}$ & $\begin{array}{l}17,11 \\
14,33\end{array}$ & $\begin{array}{l}2,98 \\
8 \\
2,52 \\
1\end{array}$ & 0,000 \\
\hline
\end{tabular}

Pada tabel 5 menunjukkan rata-rata skor tingkat kecemasan pada kelompok intervensi sebelum dilakukan dukungan spiritual adalah $17,11(S D=2,988)$. Sedangkan ratarata skor tingkat kecemasan pada kelompok intervensi sesudah dilakukan dukungan spiritual adalah 25,21 ( $S D=2,521)$. Hasil uji statistic didapatkan nilai $p=0,000$ maka dapat disimpulkan bahwa ada

Tabel 7

Analisa Rata-rata Selisih Skor Tingkat Kecemasan Pada Kelompok Intervensi dan Kelompok Kontrol di RSUD Depati Bahrin Kabupaten Bangka

\begin{tabular}{lcccc}
\hline Variabel & $\mathbf{n}$ & Mean & SD & $\begin{array}{c}p \\
\text { valu } \\
\boldsymbol{e}\end{array}$ \\
\hline Selisih & & & & \\
Intervensi & 18 & 2,7778 & 1,3956 & 0,00 \\
Kontrol & 18 & $-3,333$ & 0 & 0 \\
& & & $\begin{array}{c}1,0846 \\
\end{array}$ & \\
& & & 5 & \\
\hline
\end{tabular}


Pada tabel 7 menunjukkan bahwa, perbedaan selisih skor tingkat kecemasan sebelum dan sesudah klien pre operasi pada kelompok intervensi rata-ratanya adalah 2,777 dengan $(S D=1,3956)$. Sedangkan pada kelompok kontrol rata-ratanya adalah $-3,333$ dengan ( $S D=2,26445)$. Hasil penelitian dilakukan $u j i$ statistik lebih melihat selisih skoring tingkat kecemasan didapatkan hasil $p=0,000<0,05$ yang berarti ada perbedaan yang signifikan pada kedua kelompok tersebut.

\section{PEMBAHASAN}

Pembedahan merupakan
tindakan pengobatan yang menggunakan teknik invasif dengan membuka atau menampilkan bagian tubuh yang akan ditangani melalui sayatan yang diakhiri dengan penutupan dan penjahitan luka (Susetyowati, dkk, 2010).

Menurut Kozier (2009) yang dikutip dari Rahmayati, dkk (2018) Pembedahan adalah pengalaman yang menyebabkan stres dan perubahan fisik serta fisiologik. Pengaruh tindakan pembedahan dapat menyebabkan pengaruh psikologis pasien yang berbedabeda, namun sesungguhnya selalu timbul kecemasan dan rasa ketakutan yang umum diantaranya takut terhadap anastesi, takut terhadap nyeri akibat luka operasi, takut tentang ketidaktahuan atau takut terhadap deformitas atau ancaman lain terhadap citra tubuh yang dapat menyebabkan ketidaktenangan atau kecemasan, takut operasi gagal, dan takut kematian menurut Dharma (2017). Banyak pasien mengalami kecemasan yang cukup besar sebelum operasi dan ini dilaporkan mempengaruhi $60-80 \%$ dari pasien bedah. Peran dari tim kesehatan untuk memastikan bahwa setiap pasien menjalani elektif prosedur bedah adalah baik secara fisik dan psikologis siap (Gangadharan, Priya dkk. 2014) yang dikutip dari Purindra (2017).

Menurut Jeffrey S. Nevid, dkk, dikutip dari Annisa dan Ifdil (2016), mengatakan bahwa "kecemasan adalah suatu keadaan emosional yang mempunyai ciri keterangsangan fisiologis, perasaan tegang yang tidak menyenangkan, dan perasaan aprehensif bahwa sesuatu yang buruk akan terjadi”.

Pengertian lain cemas menurut Kusumawati dan Hartono (2010) adalah suatu keadaan yang membuat seseorang yang tidak nyaman dan terbagi dalam tingkatan. Jadi, cemas berkaitan dengan perasaan yang tidak pasti dan tidak berdaya.

Lestari (2015) juga menjelaskan kecemasan merupakan keadaan perasaan afektif yang tidak menyenangkan yang disertai dengan sensasi fisik yang memperingatkan orang terhadap bahaya yang akan datang. Keadaan yang tidak menyenangkan itu sering kabur dan sulit menunjuk dengan tepat, tetapi kecemasan itu sendiri selalu dirasakan.

Dari hasil penelitian menunjukkan bahwa rata-rata tingkat skor kecemasan pada kelompok intervensi sebelum dilakukan perlakuan adalah 17,11 dengan skor tertinggi 22 (cemas sedang) dan terendah 11 (tidak ada cemas), dan sesudah dilakukan perlakuan skor tingkat kecemasan menurun menjadi 14,33 dengan skor tertinggi 19 (cemas ringan) dan skor terendah 11 (tidak ada cemas). Sedangkan rata-rata skor tingkat kecemasan kelompok kontrol sebelum dilakukan adalah 16,28 dengan skor tertinggi 22 (cemas sedang) dan terendah 11 (tidak ada cemas), dan skor sesudah perlakuan nilai rata tingkat kecemasan meningkat menjadi 16,61 dengan skor tertinggi 22 (cemas sedang) dan 
terendah 11 (tidak ada cemas). Hasil penelitian didapatkan nilai $p=0,000$ pada kelompok intervensi maka dapat disimpulkan bahwa adanya perbedaan yang signifikan antara tingkat kecemasan sebelum dan sesudah dilakukan dukungan spiritual pada kelompok intervensi. Sedangkan kelompok kontrol didapatkan nilai $p=0,210$ maka dapat disimpulkan bahwa tidak ada perbedaan yang signifikan antara tingkat kecemasan sebelum dan sesudah pada kelompok kontrol. Pengukuran dilakukan dengan menggunakan uji statistik dependen t-test.

Dari hasil penelitian bahwa perbedaan selisih skor tingkat kecemasan sebelum dan sesudah dilakukan perlakuan didapatkan selisih skoring nilai $p=0,000<0,05$ yang berarti ada perbedaan yang signifikan pada kedua kelompok tersebut.

Penelitian ini sejalan dengan hasil penelitian Virgianti (2015) Setelah diberikan intervensi terapi murottal (al-qur'an) mengalami penurunan tingkat kecemasan, 21 pasien $(56,5 \%)$ mengalami tingkat kecemasan ringan dan 8 pasien (25\%) mengalami tingkat kecemasan sedang. ) Berdasarkan hasil uji statistik Wilcoxon Sign Rank Test, menunjukkan nilai signifikansi ( $p$ value $=0,000$ ) dimana hal ini berarti $\mathrm{p}$ value $<0,05$ sehingga $\mathrm{H} 1$ diterima artinya ada pengaruh tingkat kecemasan sesudah pemberian perlakuan terapi murottal (AlQur'an).

Penelitian ini sejalan dengan hasil penelitian yang dilakukan Apriansyah, dkk (2014), dengan judul hubungan antara tingkat kecemasan pre operasi dengan derajat nyeri pada pasien post sectio caesarea di rumah sakit muhammadiyah palembang tahun 2014 menyatakan ada hubungan yang signifikan antara tingkat kecemasan pre operasi dengan derajat nyeri post sectio caesarea. Dari hasil uji statistik menunjukan ada hubungan yang signifikan antara tingkat kecemasan pre operasi dengan derajat nyeri post sectio caesarea dengan $p$ value 0,010.

Penelitian ini sejalan dengan hasil penelitian yang dilakukan Rahmayati, dkk (2017), dengan judul pengaruh dukungan spiritual terhadap tingkat kecemasan pada pasien pre-operasi menyatakan hasil uji statistik didapat nilai $p$ value 0,001 maka dapat disimpulkan bahwa ada pengaruh terapi dukungan spiritual terhadap tingkat kecemasan pada pasien pre-operasi di RS Imanuel Provinsi Lampung Tahun 2017.

Pendapat peneliti dari hasil penelitian bahwa sebagian besar pasien pre operasi mengalami kecemasan ringan, tingkat kecemasan yang dialami seseorang tentu berbeda beda, setelah dilakukan perlakuan skor kecemasan menurun itu karena timbulnya rasa tenang dan nyaman pada diri seseorang, bisa mengontrol emosi dan pikiran setelah dilakukan dukungan spiritual. Hasil penelitian yang diketahui bahwa terdapat perbedaan yang signifikan antara kecemasan responden di Ruang Bedah RSUD Depati Bahrin Sungailiat Tahun 2019.

Jenis dukungan spiritual yang efektif menurunkan tingkat kecemasan adalah murottal al-quran untuk muslim dilakukan selama 2030 menit, responden juga bisa melakukan sendiri selama responden belum operasi. Lama kelamaan dukungan spiritual dapat menurunkan tingkat kecemasan karena mempengaruhi pikiran, emosi serta rasa khawatir akan tindakan operasi.

Penurunan tingkat kecemasan pada pasien pre operasi merupakan salah satu pengobatan non 
farmakologi pada pasien yang mengalami kecemasan pada saat sebelum operasi. Efek dari dukungan spiritual yang dilakukan secara mendalam dapat mempengaruhi pikiran, emosi serta rasa khawatir akan tindakan operasi. Hal ini disebabkan karena dukungan spiritual dapat berupa do'a, sholat, dzikir, dan membaca Al-Quran. Ketika berdoa akan menimbulkan rasa percaya diri, rasa optimisme (harapan kesembuhan), mendatangkan ketenangan, damai, dan merasakan kehadiran Allah SWT.

Peran spiritual dalam hal mekanisme koping sebagai suatu semangat, atau motivasi untuk hidup, keyakinan, pendekatan, harapan dan kepercayaan pada Tuhan serta kebutuhan untuk menjalankan agama yang dianut, kebutuhan untuk dicintai dan diampuni oleh Tuhan yang seluruhnya dimiliki dan harus dipertahankan oleh seseorang sampai kapanpun agar memperoleh pertolongan, ketenangan, keselamatan, kekuatan, penghiburan serta kesembuhan. Mekanisme koping yang terbentuk sangat tergantung pada kepribadian seseorang dan sejauhmana tingkat stres dari suatu kondisi atau masalah yang dialaminya.

\section{KESIMPULAN}

1. Rata-rata tingkat kecemasan sebelum dilakukan perlakuan pada kelompok kontrol adalah 16,28 (SD=3,707). Sedangkan rata-rata skor tingkat kecemasan sesudah dilakukan perlakuan adalah 16,61 $(S D=3,696)$. Hasil uji statistik didapatkan nilai $p=$ 0,210 maka dapat disimpulkan bahwa tidak ada perbedaan yang signifikan antara tingkat kecemasan sebelum dan sesudah pada kelompok kontrol.
2. Perbedaan selisih skor tingkat kecemasan sebelum dan sesudah klien pre operasi pada kelompok intervensi rata-ratanya adalah 2,777 Sedangkan pada kelompok kontrol rata-ratanya adalah 3,333 . Hasil penelitian dilakukan uji statistik lebih melihat selisih skoring tingkat kecemasan didapatkan hasil $p=0,000<0,05$ yang berarti ada perbedaan yang signifikan pada kedua kelompok tersebut.

\section{SARAN}

Hasil penelitian ini diharapkan dapat dijadikan acuan untuk rumah sakit mengambil kebijakan tentang penerapan pemenuhan kebutuhan spiritual pasien pre operasi dengan cara melibatkan guru spiritual. Dan juga melibatkan dokter untuk memberikan dukungan motivasi pada pasien pre operasi.

\section{DAFTAR PUSTAKA}

Agusnawati. (2013). Pengaruh Terapi Spiritual Terhadap Tingkat Ansietas Pasien PreOperasi Elektif di Ruang Bedah RSUD Dr. H. Bob Bazar, SKM Kalianda. Skripsi, Universitas Malahayati.

Apriansyah, A. Romadoni, S. Andrianovita, D. (2014) Hubungan Antara Tingkat Kecemasan Pre-Operasi Dengan Derajat Nyeri Pada Pasien Post Sectio Caesarea di Rumah Sakit Muhammadiyah Palembang Tahun 2014. Jurnal Keperawatan Sriwijaya, Vol 2-No1, 2355-5459. Annisa, D F \& Ifdil. (2016). Konsep Kecemasan (Anxiety) Pada Lanjut Usia (Lansia). Jurnal Konselor Vol 5, No 1. 1412-9760. Ardian, Iwan. (2016). Konsep Spiritualitas dan Religiusitas (Spiritual and Religion) Dalam 
Konteks Keperawatan Pasien Diabetes Melitus Tipe 2. Jurnal Keperawatan dan Pemikiran Ilmiah. 2(5). Diakses 20 Maret 2019.

file: ///C:/Users/Ade\%20M\%20Sy urga/Downloads/2234-4777-1SM.pdf.

Alligood, Martha R. (2017). Pakar Teori Keperawatan Edisi 8 Vol 1. Singapore: Elsevier Pte. Ltd.

Darma, S. Rosmaharani, S. Nahariani, P. (2017) Hubungan Pemenuhan Kebutuhan Spiritual Dengan Tingkat Kecemasan Pasien Pra Operasi. Jurnal Ilmiah Keperawatan, Vol 3, 2528-3022.

Farida, Kusumawati \& Yudin Hartono. (2010). Buku Ajar Keperawatan Jiwa. Jakarta: Salemba Medika.

Gusnia, S. (2012). Pelayanan Spiritual Pada Pasien, Siapa yang Perduli ? Vol 1, No 2. Diakses 20 Maret 2019, http://ejournal.usd.ac.id/index.php/jt/ article/view/429.

Joyce M. \& Hawks, H J. (2014). Keperawatan Medikal Bedah Edisi 8, Buku 1. (Elsevier penerjemah). $\quad$ Singapore: Elsevier Pte. Ltd.

Kozier. (2009). Buku ajar fundamental keperawatan konsep, proses \& praktik vol 2. Edisi 7. Jakarta: EGC.

Krentzman, A. R. (2013). What Is Spirituality.

Takingcharge.csh.umn.edu .

Lestari, Titik. (2015). Kumpulan Teori Untuk Kajian Pustaka Penelitian Kesehatan. Yogyakarta: Nuha Medika.

Mahdianto. (2015). Hubungan Tingkat Kecemasan Pada Pasien Post Section Cesarea di RSUD Depati Hamzah Pangkalpinang Tahun 2015. Skripsi strata satu, Universitas Citra Delima Bangka Belitung.

Parker, M., Bowers, S. P., Bray, J. M., Harris, A. S., Belli, E. V.,
Pfluke, J. M., Smith, C. D. (2010). Hiatal mesh is associated with major resection at revisional operation. Surgical Endoscopy, 24(12), 3095-3101. doi: $10.1007 / \mathrm{s} 00464-010-1095$.

Potter \& Perry. (2010). Fundamental Keperawatan Buku 2 Edisi 7 (dr. Adrina $F$ \& $d r$. Marina $A$ penerjemah). $\quad$ Singapore: Elsevier Pte. Ltd.

Purwaningsih, Wahyu. (2010). Derajat Kecemasan Pasien Dengan Tindakan Operatif Dapat Dimimalisir Dengan Persiapan Pre Operatif yang Matang. Jurnal Ilmiah Rekam Medis dan Informatika Kesehatan Vol 1, No 2. 2086-2628.

Rahmayati, E. Silaban, R N, Fatonah, S. (2018). Pengaruh Dukungan Spiritual terhadap Tingkat Kecemasan Pada Pasien Pre Operasi. Jurnal Kesehatan Vol 9, No 1, 2086-7751.

Sjamsuhidajat. (2010). Buku Ajar Ilmu Bedah, Edisi II. Jakarta: EGC.

Susetyowati, dkk (2010). Keperawatan Medikal Bedah, Jakarta.

Suherlan, (2012) Hubungan Peran Perawat Sebagai Pelaksana Dengan Tingkat Kecemasan Klien Pra Operatif Obsgyn di Instalasi Bedah Sentral RSD dr. Soebandi. Sumatera: Universitas Jember.

Triantoro Safaria \& Nofrans Eka Saputra. (2012). Manajemen Emosi: Sebuah panduan cerdas bagaimana mengelola emosi positif dalam hidup Anda. Jakarta: Bumi Aksara.

Yusuf, Ah, dkk (2016). Kebutuhan Spiritual Konsep dan Aplikasi Dalam Asuhan Keperawatan. Jakarta: Mitra Wacana Media. 